\title{
105. 上顎洞癌の遠隔転移症例の検討
}

\author{
牧野総太郎・佐竹 文介・高橋 敬一・松浦 鎮 \\ (群馬県がんセンター・頭頸科) \\ 境野 宏治同・放射線部）
}

上腼洞扁平上皮がんの遠隔転移は比較的少いとされる が, 最近, 局所が制御されながらも, 腹部臓器を中心と した遠隔転移により早期死亡した 2 症例を経験し，あら ためて過去 9 年間 $(1973-81)$ の上顎洞扁平上皮癌剖検 例について, 頻度, 遠隔転移部位, 遠隔転移時期, 局所 および所属リンパ節転移の制御の有無, 死因について分 析検討し，上顎洞癌治療にあたって留意すべきことがら を探った。

結 果

1. 上顎洞癌死亡例 50 例中, 25 症例 (男 17 例, 女 8 例) に剖検し得た。2. 上堮洞癌剖検例 25 症例のうち，遠 隔転移例は男 4 例，女 3 例の計 7 例 $(28.0 \%)$ で，年龄 は46歳から83歳でその分布は一様であった。3，上顯洞 癌の遠隔転移は，肺だけに転移した 3 症例と肝臟を主と した腹腔内転移を中心とする複数臟器に転移した 4 症例 の群に分けると, 肺単独転移群の腫崵の分化度はより高 分化型であり, 平均生存期間は複数臟器転移群の 6 カ月
より長い 1 年 6 カ月であった。 4 .また複数臟器転移群 の中に局所は制御されながらも早期死亡した 2 症例があ り, その他の遠隔転移例では, 局所, 芹属リンパ節転移 宩は制御されていなかった。 5 ，遠隔転移時期は，肺単 独転移群は局所再発後 9 力月前後であるのに対して, 複 数藏器群のそれは 5 カ月前後であった。6. 剖検により はじめて遠隔転移が判明した，つまり潜在性の遠隔転移 例は, 肝臟，胸椎，皮膚に小さな転移栄をもった 1 症例 で，その比率は剖検例に対して $4 \%(1 / 25)$ ，遠隔転移例 に対して14.3\%（1/7）であった。

まとめ

上䫑洞癌の遠隔転移の様式には, 肺単独に転移する様 式と腹部臟器を主とした複数藏器へ転移する様式がほぼ 同頻度にあり，遠隔転移時期，生存期間もその様式によ り若干異なることをふまえ，局所の経過観察とともに， 肺のみならず全身的な定期的チェックの必要性を再認識 した。

\section{上顎肉腫 106～111}

\section{座長のまとめ}

熊沢 忠躬（関西医科大学・耳鼻咽喉科）

上顥腫瘍の $70 \%$ 以上は癌であり, 肉腫は $6 \sim 10 \%$ とい われている。診断法，治療法が発達した今日でも，この 疾患の予後の悪いことが特筆出来る。この点に関して浅 井教授にコメントを抢願いします。 〔浅井教授のコメント]
肉腫は放射線効果が癌の場合より著しい。私は早く診 断を下し，手術をし，その後徹底的に放射線治療をする 事を方針にしている。線維肉腫で 8 年生存率の経験があ ります。 


\title{
106. 上顎洞に発生した malignant fibrous histiocytoma の 2 例
}

\author{
大橋 直樹 - 麻生 伸 - 渡辺 行雄 - 水越 鉄理 \\ (富山医科薬科大学 $\cdot$ 耳鼻咽喉科)
}

\begin{abstract}
Malignant fibrous histiocytoma (MFH) は Sharon らの報告にもある通り, 主に下肢, 上肢, 腹腔, 後腹膜 に発生する組織球由来の悪性腫瘍であるとされている。 副鼻腔に発生した $\mathrm{MFH}$ は極めてまれであり, 又その 治療法も確立していない。今回私達は上顎洞に発生した $\mathrm{MFH}$ の 2 症例を経験したので報告した。症例 1 は, 62 歳の男性であり昭和56年10月頃から，左鼻閉，鼻出血を 主訴として当院を受診した。CT，Tomoでは上顎洞前 壁，後壁に骨破壊が認められた。病理結果は MFH であ り $5 \mathrm{FU}$ 動注と共に $7000 \mathrm{rads}$ の放射線療法を行ない又 Denker 術む行ったが, 再発のために眼球も含めた上頢 全摘出を行った。局所の腫湯増大，肺，肝への転移のた めに死亡した。症例 2 は68歳の女性で, 昭和57年10月頃 に右煩部痛を主訴に当院を受診した。CT 上では上顎洞 前後壁に明らかな骨破壊があり，病理診断で $\mathrm{MFH}$ と 診断された。アドリアシン静注, PEP 動注, $1400 \mathrm{rads}$ 照射を行ったが肺炎で急死した。症例 1 では光顕的には
\end{abstract}

長楕円形， 紡錐形の腫瘍細胞が認められた， storiform pattern も散見される通常型 pleomorphic subtype と考 えられる所見が得られた。又電顕的には hstiocyte like cell, fibroblast like cell 等の 5 種類の腫場細胞が確認さ れた。症例 2 の光顕的所見は, storiform pattern が著明 な通常型 storiform subtype と考えられた。電顕的には fibroblast like cell と histiocyte like cell が混在した。病 理学的には，診断は難しく， O’brien \& Stout が fibrous histiocytoma に含れている腫瘍の中から腫瘍細胞の 高度の分裂，浸潤又は転移の明らかなものを $\mathrm{MFH}$ と 診断した。我々の 2 症例でも診断に至るまでに，単なる 炎症細胞又は reticulum cell sarcoma 等の診断を経た。

我々の経験からは, radiation は有効でなく，広範囲な 外科的切除が必要と思われた。また，化学療法について は，アドリアシンが有効とする報告があるが我々の経験 からは不明であった。

\section{7. 上顎部 fibromatous tumor $の 2$ 症例}

奥野 吉昭 - 山下 敏夫 - 甲田 容子 - 熊沢 忠躬 （関西医科大学・耳鼻咽喉科）

泉 春暁 (同・中検病理)

副鼻腔悪性腫場の内，肉腫の発生頻度は $10 \%$ 程度であ る。そのうち線維肉腫についての報告は意外に少く, 本 邦でも19例にすぎない。今回我々は若年女児に発生した 病理組織上 fibrosarcoma，及び fibromatosis と診断さ れた症例を経験したので報告する。第 1 例14歳女児。約 5 カ月前より徐々に増大寸る右煩部無痛性腫脹を主訴と して来院。C. T. 上, 右上顎洞全体に充満した腫演陰影 を認めた。腫崵は骨破壞を伴い，前方は上頻骨顔面壁を 越え, 側方は煩骨弓を, 後方は顽椎付近まで達する腫瘤 を認めた。右上顎洞肉腫を疑い右上顎骨と伴に腫場全摘 出術を施行した。第 2 例 8 歳女児。約 2 カ月来, 徐々に増 大する右煩部無痛性腫脹を主訴として来院。初診時, 埋 没歯芽を含む境界明膫な上頷洞部腫瘤陰影を認め滤胞性 歯芽囊腫を疑い試験穿刺を行ったが排液なく充実性の低 抗があった。全麻下腫瘍を一塊として摘出した。手術時 上顎洞は腫湯にて圧排され，骨壁は半紙様に菲薄化して いた。 病理 : 症例 1 は細長い核と胞体を有する著明な 核異型を示す細胞が密に存在し，その一部が Herring- bone pattern を呈し上顎洞原発の fibrosarcoma と診断 された。症例 2 は少数の mitose, 核の大小不同を有する 紡鍾型の細胞が豊富な collagen fiber を伴って, fibrosaroma と比較し疎に出現し, fibromatosis と診断され た。手術所見では腫瘍上部に永久歯が存在していた。腫 瘍摘出術後歯肉部の久損が認められた。摘出標本の上部 には上顎洞骨壁の一部と考えられる骨組織を認めた。以 上の事よりこの症例は，上顎洞原発の腫瘍とは考えられ ず，歯肉の fibrocyte 由来のものかあるいは歯原性の細 胞由来のものあるいは歯原性の細胞由来のものかいづれ かの原発による腫瘍でこれが上頷洞に向ってあたかも濾 胞歯芽囊腫の如く増大した。充実性の非上皮性腫瘤であ ると結論された。まとめ: 症例 1 は上顎洞原発 fibrosarcoma で病理組織上の悪性度に比例してその予後も悪 く, 術後約 6 力月後再発を来した。症例 2 は上箩洞外組 織より発生したが臨床的には上顎洞腫湯と診断され治療 された。このような臨床経過を呈する腫陽の報告は現在 まで皆無であった。以上 2 症例につき報告す。 


\title{
108. 上顎洞に発生した Hemangiopericytoma pattern を取った fibrous histiocytoma の一剖検例
}

\author{
五島 可喜・中島 幸洋・竹山 勇
}

(聖マリアンナ医科大学・耳鼻咽喉科)

鼻腔及び副鼻腔原発の悪性線維性組織球腫（Malignant fibrous histiocytoma 以下 MFH と略) の報告は極め て少ない。今回我々は左上顎洞原発の $\mathrm{MFH}$ の一例を 経験したので, その臨床経過を述べると共に, 若干の文 献的考察を加えて報告した。患者は67歳の男性で，歯肉 腫瘤を主訴に某歯科受診し，当科紹介され，昭和57年 7 月15日入院となった。家族歴及び既往歴には特記すべき 事はない。入院時左上歯肉部に $2 \times 1.3 \mathrm{~cm}$ の赤褐色易出 血性腫瘤を認め，生検にて血管外皮腫の疑いと診断され た。入院時検查所見では, WBC 15500 , 血沈 $35 / 66$, $\mathrm{CRP} \pm$ ，で他には異常所見は認めなかった。レ線学的検 查では，左上顎洞のび漫性腫湯陰影と，上顎洞下壁及び 側壁の骨破壊像が認められた。入院後, 腫崵が急激に増 大したため，同年 7 月27日，全麻下にて上䪽全摘出術を 施行した。手術時腫瘍は洞内に充満しており，歯肉部の 腫瘍と交通していた。又，術後早期に腫瘍の局所再発を 来した為，ADR 軟亭と necrotomy による局所療法を
開始したが効果ないため，篇重な全身管理下にて総量 90mg の ADR 全身投与を行なった。しかし腫瘍増大傾 向著しいため，OK-432を併用しながら総量 $43.0 \mathrm{~Gy} の$ 照射を行なったが，殆んど反応せず同年10月 7 日全経過 約 3 カ月で死亡した。病理解剖の結果，肺・肝・骨䯣な ぞへの全身転移を認め，摘出標本と剖検時標本のさらに 細かい病理学的検索により，血管外皮腫様組織像を呈し た $\mathrm{MFH}$ との診断が下された。本症の診断は極めて困 難で，軟部組織の多形性細胞の出現する肉腫は全て鑑別 疾患であり，血管外皮腫・横紋肉腫・平滑筋肉腫・線維 肉腫等がある。fibrous histiocytoma は一般に良性像を 呈するむのが多く, 組織学的検索のみから良性悪性を決 定する事は極めて困難であるため，臨床所見も重要な決 定因子となると思われる。又，MFH はしばしば局所再 発を繰り返す事が多く，放射線療法・化学療法も効果が 少なく，血行性・リンパ行性に転移する可能性が高いた め，早期に広範囲に切除する事が必要と思われる。

\section{9．上顎骨肉腫の 1 症例}

沖中 芳彦・関谷 透・西川 益利 - 奥園 達也

野口高昭少濞咽喉科)

骨肉腫は骨原発性腫場のうちでは発生頻度も高く, 極 めて悪性度の高い腫癔であるが，通常長管骨の骨幹端部 に好発し，顎顔面骨に発生することは稀とされている。 今回我々は上頻骨に原発した骨肉腫の 1 例を経験したの で報告した。

症例は15歳女性で，約 2 カ月前より徐ヶに増大する右 煩部腫脹を主訴に昭和55年 5 月 28 日当科受診。圧痛およ び軽度の開口障害を伴っていた。右煩部に $5 \times 5 \times 1 \mathrm{~cm}$ の軟骨様硬の腫瘤を触知した。同部の外傷，放射線照射 の既往はなかった。X線検查で上顎骨外側壁を中心に洞 内および外側皮下にむから腫瘤状陰影を認めた。

同年 6 月 12 日, 右上䫑洞試験開洞, 腫瘤摘出術を施 行。摘出された腫瘤は貝柱樣の外観を呈していた。

病理組織学的には, 異型性の強い腫瘍細胞が閒質に類 骨を形成している像が認められ，骨肉腫と診断された。

上顎全摘の同意が得られなかったため，放射線療法

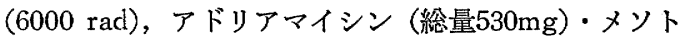
レキセート(総量 $3500 \mathrm{mg}$ ) による化学療法を施行したが
局所再発浸潤傾向が強く, 56 年 9 月右上頻部分切除, 再 発のため同年12月腫湶摘出・右眼球摘出術施行。さらに 頭蓋内への浸潤のため昭和57年 6 月本学脳外科にて頭蓋 内腫瘍の摘出を行なった。同年11月，左肺門部への転移 が明らかになり，同部に放射線照射（5100 rad）を行な うも効果なく増大傾向にある。また，58年 2 月には脳へ ルニアをきたし，再び開頭，腫演摘出を行なった。初診 から 3 年の時点で，左肺および頭部に腫瘍残存のまま生 存している。

（考察）骨肉腫は原発巣の完全除去後も高率に肺転移 をきたす極めて予後不良の疾患である。滪骨原発の骨肉 腫では解剖学的に完全摘出が困難な場合もあり, 局所再 発浸潤が直接の死因となることも多い。本症例では最初 家族の反対もあり積極的な治療を行ない得なかったが， 局所浸潤傾向の非常に強い本腫湯の性格を考えると，初 回治療としてはやはり可及的広範切除を行なうべきであ ったと反省している。 


\section{0。顎骨に発生した骨肉腫の 2 症例}

増山 敬祐・猪川勉・東家 倫夫・石川 䓔

(熊本大学 $\cdot$ 耳鼻咽喉科)

最近我々は, 䫟骨に発生した骨肉腫を経験した。2 例 とも不幸な転帰をとったが治療の反省も含め若干の文献 的考察を加えここに報告する。症例 1 は 12 歳男性。 3 カ 月前より左耳介前下部の有痛性腫脹が出現。某医で投薬 にて経過観察していたが，1カ月前より開口障害が出現 したので紹介来院した。所見・検查より耳下腺炎を疑い 抗生剂にて経過観察していたが腫脹消失なく手術を施行 した。術中所見は，下頡上行枝からでた腫瘍で骨膜を破 壞し周囲組織に強く浸潤していた。術後骨肉腫の診断の もと, Linac X-ray, プレドニン, エンドキサン, OK432を使用したが 4 力月後局所再発をきたし肺転移にて 死亡した。症例 2 は14歳女性。3 カ月前より右上歯肉の 無痛性腫脹出現。某医にて腫瘍摘出術を受け骨肉腫の診 断によりメソトレキセート大量療法施行中であったが局 所再発をきたしたため当科紹介となった。右煩部腫脹著 明で眼窩下壁は破壊され右口蓋部は腫湯で占められてい た。右上顡全摘出術を施行し術後整形外科にてメントレ
キセート大量療法を行ったが再び局所再発をきたし術後 5 カ月で死亡した。

頷骨原発骨肉腫の発生は 7 \%前後で，骨盤骨と同等の 発生をみる部位である。好発部位は，本邦では下顎骨し かも歯部である。症例 1 のごとく下顎枝部に発生する のは少ない。治療は, 外科的切除に加え, 最近では高圧 X線や速中性子線照射，大量制癌剤投与などがとり入れ られ，これらの併用療法により治療成績の改善がみられ る。予後に関して奥山らも述べているごとく，予後のキ イポイントは局所制御にかかわっている。症例 1 では当 初耳下腺炎を疑われ局所制御を遅らしたようだ。一般の 骨肉腫に比べ予後がよいため, Kragh は，1回目の姑息 的は手術に失敗しても 2 回目に根治的手術を行えば cu一 re のチャンスがあると述べている。症例 2 は 2 回目の 手術でも局所制御ができなかった。局所制御を積極的に 行い，上に述べた各種治療をとり入れることにより，よ り高い生存率が期待できると考えた。

\section{1。両側性網膜芽細胞腫に続発した上顎骨肉腫の一例}

一林 正剛・田中 克彦・寺山 吉彦 (北海道大学・耳鼻咽喉科)

症例は 6 歳男児。昭和50年11月, 生後 1 カ月にて北大 病院眼科で両側性網膜茅細胞腫の診断を受け，右眼球摘 出術, 両眼部に $\mathrm{Co}^{60}$ 外照射を受けた。その後経過順調で あったが，昭和56年12月中旬より右煩部腫脹が出現した 為, 当科紹介され受診。家族歴では祖母に膀胱癌を認め た。初診時, 右煩部に著しい腫脹を認め, 右鼻腔に腫陽 塊が充満し, 右煩荬槽湮より腫瘍塊が下垂, 歯槽, 口蓋 もび漫性に腫脹し正中まで達していた。レントゲン断層 写真では右節骨洞, 鼻胵, 眼窩, 上頻洞に連続する陰影 を認めた。CT スキャンでは右上䫇部に極めて dense で 骨様の陰影を認めた。 $\mathrm{Co}^{60}$ 照射後, 上頷全摘出術により 腫瘍摘出を行った。摘出標本にて骨肉腫の病理診断を得 た。網膜芽細胞腫は我が国では眼内悪性腫瘍のなかで最 も多く, 且つ小児悪性新生物のなかでも白血病, 西性り ンパ腫に次いで多い疾患である。両眼性網膜芽細胞腫は そのすべてが遺伝性（大多数が 新生突然変異による）
であり，片眼性孤発例の大多数は非遺伝性である事が 知られている。又治療後別種の腫瘍が眼部以外, 通常既 照射部位，一部は遠隔に発生する事が知られている。 Segermann らは両側性網膜芽細胞腫患者において, 放 射線々量と続発腫湯の発生率に正の相関を認めたと報告 し, 一方 Abramson らは照射患者群と非照射患者群とに おける続発腫瘍の発生率に差がなかった事から, 続発腫 瘍の発生には放射線治療は無関係であると述へ, 続発腫 瘍発生一の遺伝的素因の関与を示唆し, 両眼性急者にお ける続発腫場の発生頻度を15２0\%と推定した。しかし 現在の所, 続発腫演の発生と放射線照射及び遺伝的素因 との関連性についての正確な結論は出ていない。続発腫 瘍として最も多いのは骨原性肉腫で $80 \%$ を占める。我が 国での本症の続発腫湯については線維肉腫 2 例, 血管周 囲細胞腫 1 例, 骨肉腫 1 例, 計 4 例の報告があります。 